\title{
ロジウム電極を用いたコルベ反応の研究*
}

\author{
岡 村 朝 彦** \\ Studies on the Kolbe Reaction with Rhodium Electrode \\ Tomohiko OKAMURA \\ ( $\left.\begin{array}{c}\text { Faculty of Engineering, Kanto Gakuin Univ. } \\ \text { 4834, Mutsuura, Kanazawa-ku, Yokohoma }\end{array}\right)$

\begin{abstract}
"Kolbe reaction" was studied with rhodium electrode in $2 \mathrm{MCH}_{3} \mathrm{COOH}-2 \mathrm{MCH}_{3} \mathrm{COONa}$ and $0.2 \mathrm{MCH}_{3} \mathrm{COOH}-0.2 \mathrm{MCH}_{3} \mathrm{COONa}$ solutions.

Polarization curves were obtained by the potential step method and compared with those of platinum electrode under the same condition as rhodium. Polarization at rhodium electrode was lower than that at platinum. Current efficiencies of the Kolbe reaction (i.e. $\mathrm{CH}_{3} \mathrm{COO}^{\prime} \rightarrow 1 / 2 \mathrm{C}_{2} \mathrm{H}_{6}+$ $\mathrm{CO}_{2}$ ) and other side reactions were determined by analyzing the gas evolved at the anode. Oxygen gas evolution at rhodium electrode was greater than that at platinum electrode. The anodic reaction at rhodium electrode was characterized by the occurrence of other side reactions without gas evolution.
\end{abstract}

1 はじめに (Introduction)

コルベ反応については古くより杉野ら゙による詳細な 研究があるが，いずれる陽極材料として $\mathrm{Pt}, \mathrm{Au}, \mathrm{Pd}$, $\mathrm{PbO}_{2}$ が使用されていて Rh 陽極の挙動についてはまだ 研究が行なかれていない，箨者は酶酸一酢酸ナトリウム の水溶液について Rh 陽極として陽極分極曲楾, およ び陽極生成気体をガスクロマトグラフィーにより分析 し，また陽極発生ガスの総量より電流勃率を測定した. この場合の電極反応とそれに続く遊離基生成反応は次の ように考えられている21.

$$
\begin{aligned}
& \mathrm{CH}_{3} \mathrm{COO}^{-}-e \rightarrow \mathrm{CH}_{3} \mathrm{COO} . \\
& \mathrm{CH}_{3} \mathrm{COO} \cdot \rightarrow \mathrm{CH}_{3} \cdot+\mathrm{CO}_{2} \\
& \mathrm{CH}_{3} \cdot+\mathrm{CH}_{3} \cdot \rightarrow \mathrm{C}_{2} \mathrm{H}_{6}
\end{aligned}
$$

(1) は電極反応であるが (2), (3) は完全な化学反 応であり，Pt 極では $2.10 \mathrm{~V} \sim 2.30 \mathrm{~V}$ (S.C.E.) で (1)，(2)，(3) が完全に 起こることが電解生成物の $\mathrm{CO}_{2}$ と $\mathrm{C}_{2} \mathrm{H}_{6}$ のモル比より㩆明された. $2 \mathrm{~V}$ 以下では ます酸素の発生が起こり, 電位が上昇するにつれて反応 がコルべ反応に移行することが青柳 ${ }^{3}$ により確められ た.

\footnotetext{
*ロジウムの電気化学的性唬に関する研究(第 6 報) Electrochemical Properties of Rhodium (Part 6) 昭和 42 年 10 月化学系学協会 連合大会 (岡山) にて発表

** 関東学院大学工学部 (神奈川県横浜市金呮区六溥町 4834)
}

\section{2 実験方法および結果}

(Experimental Methods and Results)

\section{1 分極曲線}

2.1.1 分極曲線の測定 分極曲線の測定は Potential Step 法により各 $0.1 \sim 0.2 \mathrm{~V} こ ゙ と に 1$ 分間放置して 電流を測定した，照合極は飽和カロメル極を用い，中間 液は飽和 $\mathrm{KCl}$ 液と電解液を用いた. 電位の規制は自製 のPotentiostat を用いた. ロジウム極の形状，大きさ， その他の条件は前報告*1 と同様である. 電解液および電 極は次の通りである.

電解液 (1) $4 M$ 酢酸一酢酸ナトリウム溶液

$$
\begin{cases}\text { 酢 酸 } & 2 M \\ \text { 酢酸ナトリウム }\left(\mathrm{CH}_{3} \mathrm{COONa}\right) 2 M\end{cases}
$$

(2) $0.4 M$ 液; (1)の電解液を 10 倍に稀釈し た.

試料極 Rh および $\mathrm{Pt}$

対 極白金網

2.1.2 ロジウム極 電極のロジウムはベンゾール 中にて 0-6 ェメリー紙にて摩き，希硫酸中にて陰極処 理, 陽極処理を行ない, 別の電解液中にて水素発生を 5 分間行ない，空気にふれぬように注意して電解液に移し た.

\footnotetext{
*1 口ジウム陽極による臭化ナトリウムの電解酸化, 本誌 $37,629(1969)$.
} 


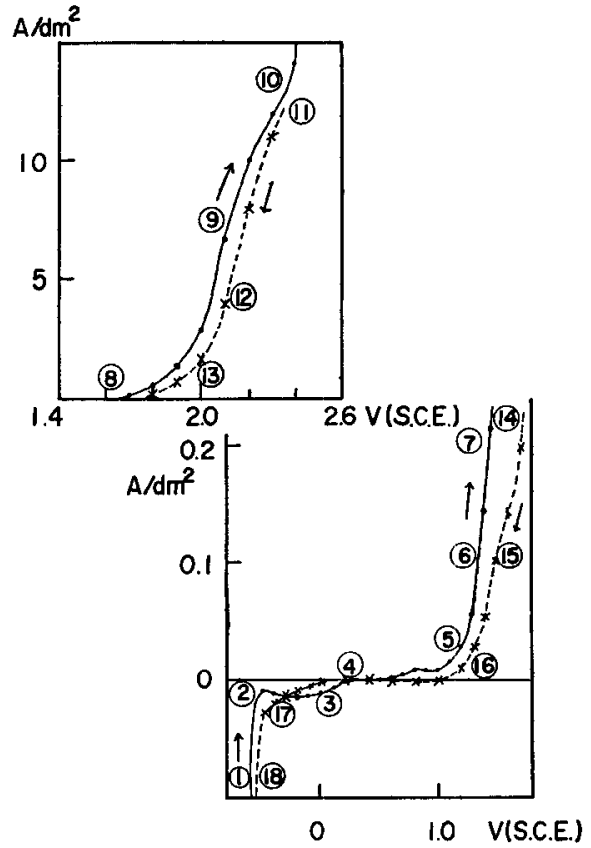

Potential step method: Keeping 1 minute after setting the potential

Electrolyte : $\left(\mathrm{CH}_{3} \mathrm{COOH}, 2 \mathrm{M}-\mathrm{CH}_{8} \mathrm{COONa}, 2 \mathrm{M}\right)$ $20^{\circ} \mathrm{C}$

Fig. 1 Polarization curve of rhodium electrode

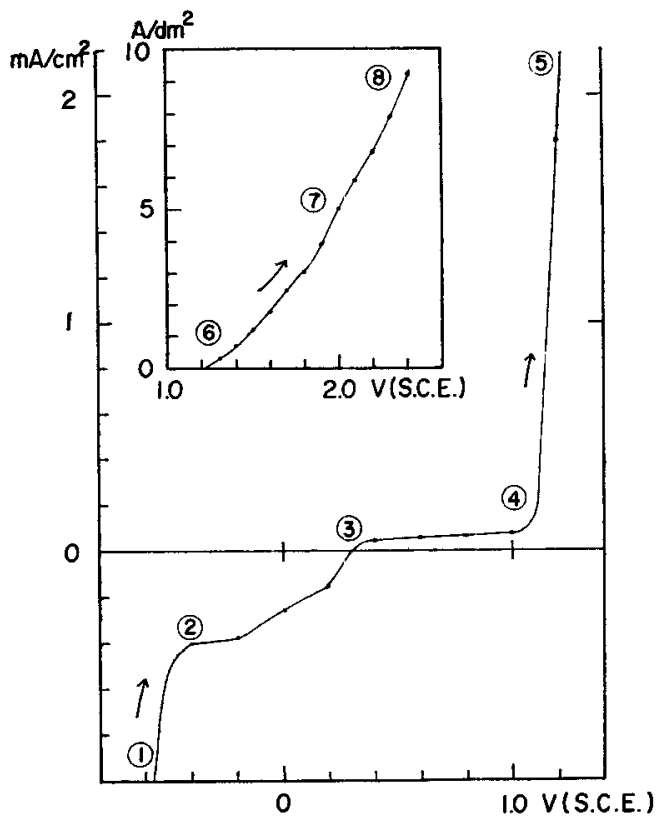

Potential step method : Keeping 1 minute after setting the potential

Electrolyte : $\left(\mathrm{CH}_{8} \mathrm{COOH}, 0.2 M-\mathrm{CH}_{3} \mathrm{COONa}, 0.2\right.$ M) $20^{\circ} \mathrm{C}$

Fig. 2 Polarization curve of rhodium electrode
1) $4 M$ 液, $20^{\circ} \mathrm{C}$ (Fig. 1) 水素発生電位 (1)より測 定開始，(2)におけるピークは電極表面の吸着水素のイ オン化 $\left(\mathrm{H} \rightarrow \mathrm{H}^{+}\right)$と溶液中の酸素の還元電流との合成 と考えられる*1. (3)における還元電流は溶液中の酸素の イオン化 $\left(\mathrm{O}_{2}+2 \mathrm{H}_{2} \mathrm{O}+4 e \rightarrow 4 \mathrm{OH}^{-}\right)$電流であるう. (4) においてロジウム表面に酸化被膜（おそらくは $\mathrm{Rh}_{2} \mathrm{O}$ お よびRh ${ }_{2} \mathrm{O}_{3}$ ) が生成し，(5)にお゙けてさらに高次の酸化被 膜 $\mathrm{RhO}_{2}$ が生成すると考えられる*2. (6) (7)〜8)の急速 な電流の増加は $\mathrm{H}_{2} \mathrm{O}$ の酸化による酸素の発生の開始で ある. (9)においてゆるやかなクニックが認められるが， これはこの点の電位 $(2.1 \mathrm{~V})$ より推定して酸素の 発生 に代わってコルベ反応が行なわれ始める電位であると考 えられる．電位降下の際も (12)にわずかなクニックが認 められる。

2) $0.4 M$ 液 (Fig. 2) $\left(20^{\circ} \mathrm{C}\right) 0.4 M$ 液に拈いては, 曲線の上昇 (6) は約 $1.2 \mathrm{~V}$ で $4 M$ 液の $1.5 \mathrm{~V}$ (8)に比べ て電位が低いのは白金にも認められた現象である。これ は酢酸イオンの濃度が酸素の発生に影響を与えるためと 考えられる.（液の $\mathrm{pH}$ はほぼ一定.)

2.1.3 白金極 $\left(20^{\circ} \mathrm{C}\right)$ 白金極学陽極としたコルベ 反応の陽極分極曲楾は既に杉野，関根 ${ }^{4), 6)}$ により測定さ

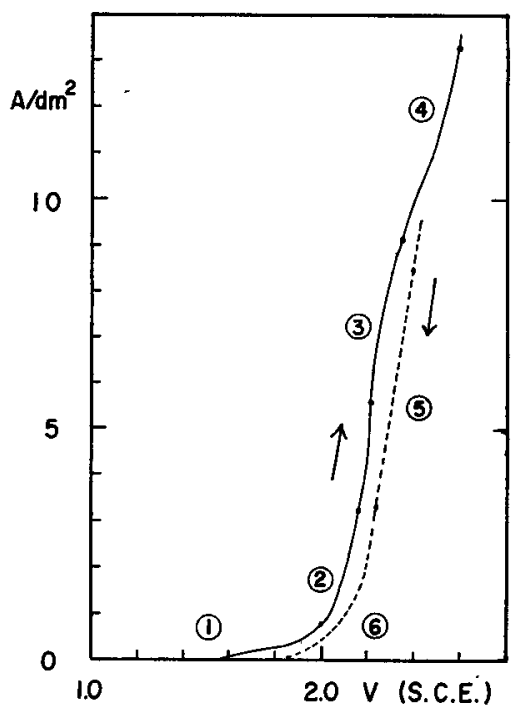

Potential step method : Keeping 1 minute after setting the potential

Electrolyte : Same as Fig. 1

Fig. 3 Polarization curve of platinum electrode

*1この場合ピークは見かけ上還元電流であるが，実は酸化電流ピーク $\left(\mathrm{H} \rightarrow \mathrm{H}^{+}\right)$と息元電流 $\left(\mathrm{O}_{2} \rightarrow 4 \mathrm{OH}^{-}\right)$の代数和である. Pot. Sweep 法により速い测定を行ならときは酸化電流が大であるためにピークは 酸化電流となるが，時間が経過すると水素のイオン化電流は段々減少 ナるゆえおてい測定では全体として道元電流として現われる場合し ある。

*2 この点は Pourbaix の電位-pH 図“Rh の部”上り溶液は $\mathrm{pH} 4.5$ 〜5.0として推定した：の Pourbaix のダイヤタラムは次報（第 7 報）に述へる。 


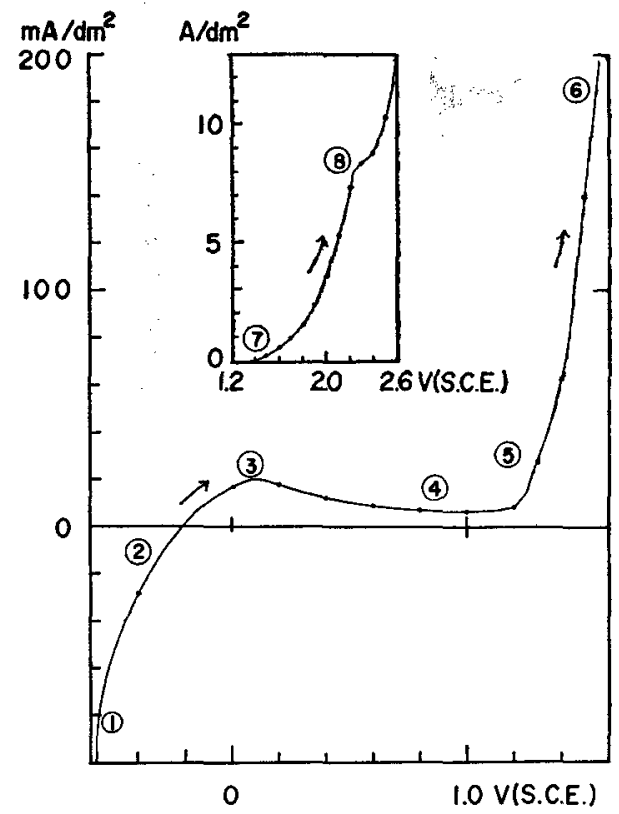

Potential step method: Keeping 1 minute after setting the potential

Electrolyte : Same as Fig. 2

Fig. 4 Polarization curve of platinum electrode

れているが，比較のため $4 M$ および $0.4 M$ 液につい て測定を行なった. (Fig. 3,Fig. 4). $4 M$ 曲線におけ る $1.5 \mathrm{~V}$ よの曲線の立ち上がり泣酸素の発生開始であ り，2.3V 付近のゆるやかなクニックはコルベ反応への 移行であると考えられる.0.4 $M$ における分極曲線の (8) におけるクニック $(2.2 \mathrm{~V})$ はやはりコルベ反応が高電流 效率で開始される電位であろう。

2.1 .4 ロジゥム極と白金極との比較 $4 M$ 液にお ける Rh 極拉よび Pt 極の分極曲線を比較すれば, Table 1 よりロジウムの方が酸素過電圧が低く, 酸素の発生が 容易であるが, 高電位になれば，電流密度の差が少なく なり，黒鉛の分極曲線に近い值となる。

Table 1 Comparison of anodic polarization of rhodium and platinum electrode Electrolyte : $\mathrm{CH}_{8} \mathrm{COOH}, 2 \mathrm{M} .-\mathrm{CH}_{3} \mathrm{COONa}, 2 \mathrm{M} .20^{\circ} \mathrm{C}$

\begin{tabular}{c|c|c}
\hline \multirow{2}{*}{ Anode potential $(V)$} & \multicolumn{2}{|c}{ Current density, $\mathrm{A} / \mathrm{dm}^{2}$} \\
\cline { 2 - 3 } & $\mathrm{Rh}^{*}$ & $\mathrm{Pt}^{*}$ \\
\hline 1.9 & 1.3 & 0.3 \\
2.0 & 3.1 & 0.7 \\
2.1 & 6.0 & 1.8 \\
2.2 & 9.1 & 5.0 \\
2.3 & 10.7 & 8.0 \\
\hline
\end{tabular}

\footnotetext{
* Anode
}

\section{2 陽極発生ガスの分析および電流効率}

2.2.1陽極発生ガスの組成陽極においてコルベ

Table 2 Constituents of gas evolved on anode by gaschromatographic analysis Electrolyte : Same as Table 1 Electrode : Rhodium Carrier gas : $\mathrm{He}, 60 \mathrm{~m} l / \mathrm{min}$

Stationary phase : Activated charcoal, length $2 \mathrm{~m}$ Column temp. : $80^{\circ} \mathrm{C}$ Sample gas : $1 \mathrm{ml}$

\begin{tabular}{c|c|c|c|c|c}
\hline $\begin{array}{c}\text { Current } \\
\text { density } \\
\left(\mathrm{A} / \mathrm{dm}^{2}\right)\end{array}$ & \multicolumn{4}{|c|}{ Composition of gas evolved on anode $(\%)$} \\
\hline 10 & $\mathrm{O}_{2}$ & $\mathrm{CH}_{4}$ & $\mathrm{CO}_{2}$ & $\mathrm{C}_{2} \mathrm{H}_{6}$ & $\begin{array}{l}\mathrm{CO}_{2} / 1 / 2 \mathrm{CH}_{4} \\
+\mathrm{C}_{2} \mathrm{H}_{8}\end{array}$ \\
\hline 5 & 5.6 & 0.4 & 64.8 & 31.2 & $1 / 0.48$ \\
5.8 & 1.2 & 64.2 & 28.9 & $1 / 0.46$ \\
\hline
\end{tabular}

反応が完全に行なわれれば（2）式と（3）式より $\mathrm{CO}_{2}$ と $1 / 2 \mathrm{CH}_{4}+\mathrm{C}_{2} \mathrm{H}_{6}$ のモル比が 2:1 になるはず であり，また発生ガス中の酸素含有量と総ガス発生量よ り電流効率の算出が可能である.

ガス採取時の条件は次の通りである.

陽 極: ロジウム板, $3.70 \mathrm{~cm}^{2}=(0.95 \mathrm{~cm} \times 1.95 \mathrm{~cm})$ $\times 2$

陰 極 : 白金スパイラル

電解液 : $\left(\mathrm{CH}_{3} \mathrm{COOH}, 2 \mathrm{M}-\mathrm{CH}_{3} \mathrm{COONa}, 2 \mathrm{M}\right), 20^{\circ} \mathrm{C}$ Fig. 5 の電解ビンを用い, 中央の陽極室を電解液で充満 し，ゴムせんにて密閉して空 気が残らないようにした。発 生ガスは最初 10 分間比発生 した分は捨て，その後の分を 適当量とった. 試料の採取は 上部のゴムせんに注射針を通 し注射器中に気体を移しガス クロマトグラフ法により， $\mathrm{CO}_{2}, \mathrm{O}_{2}, \mathrm{CH}_{4}, \mathrm{C}_{2} \mathrm{H}_{6}$ の含有 量を分析した.

その結果を Table 2 に示 した.ここで $10 \mathrm{~A} / \mathrm{dm}^{2}, 5$ $\mathrm{A} / \mathrm{dm}^{2}$ においてともに $\mathrm{CO}_{2}$ / $1 / 2 \mathrm{CH}_{4}+\mathrm{C}_{2} \mathrm{H}_{6}$ は 2:1 k 近く, $\mathrm{O}_{2}$ 発生以外の気体を 発生する反态はほとんどコル べ反応であることが認められ る.

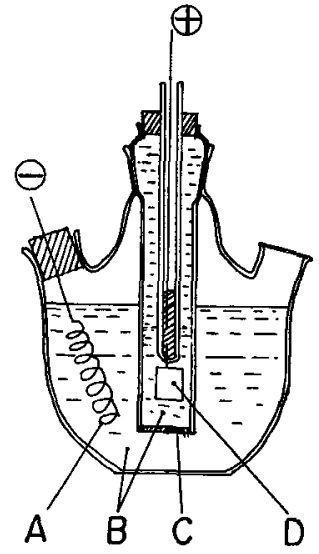

A : Cathode (Pt spiral) B : Electrolyte C : Sintered glass D : Anode

Fig. 5 Cell for analysis of evolved gas from anode

\subsection{2 陽極発生ガス量の測定電解液:} $\left(\mathrm{CH}_{3} \mathrm{COOH}, 2 \mathrm{M}-\mathrm{CH}_{3} \mathrm{COONa}, 2 \mathrm{M}\right), 20^{\circ} \mathrm{C}$.

陽極：ロジウム板

陰極：白金網

陽極発生ガスの総量と電気量の関係を求めた. 電解に は Fig. 5 の電解ビンを用い，中央部を陽極室として電 解液を充満しゴムせんにて密封し，10１5 分電解して 


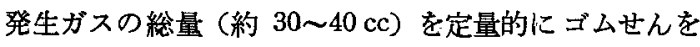
通して注射器中に移し，それよりガスビュレットに移 して容積を測定した. ガスビュレットの水準液には流動 パラフィンを用い, 通電量の测定は銅電量計を用いた. 測定の結果は $10 \mathrm{~A} / \mathrm{dm}^{2}$ において $1.19 \mathrm{~mol}$ gas/Faraday， $5 \mathrm{~A} / \mathrm{dm}^{2}$ において $1.09 \mathrm{~mol}$ gas/Faraday であった.

2.2.3 各陽極反応の䨩流効率の計算 酸素の発生 以外のガス発生反応はコルベ反応のみであるとしてガス ク口分析結果の陽極ガスの組成を次のごとく表とする (いずれもモル組成).

$$
\left\{\begin{array}{lr}
\mathrm{O}_{2} \text { の割合 } & a \times 100 \% \\
\mathrm{CO}_{2} \text { の割合 } & b \times 100 \% \\
\mathrm{C}_{2} \mathrm{H}_{6}+1 / 2 \mathrm{CH}_{4} \text { の割合 } & 1 / 2 b \times 100 \%
\end{array}\right.
$$

$\mathrm{O}_{2}$ 発生の反応は $2 \mathrm{H}_{2} \mathrm{O}-4 e \rightarrow \mathrm{O}_{2}$ であるから

$1 F$ につき $1 / 4 \mathrm{~mol} \mathrm{O}_{2}$ コルベ反応は $\mathrm{CH}_{3} \mathrm{COO}^{-} \rightarrow 1 / 2 \mathrm{C}_{2} \mathrm{H}_{6}+\mathrm{CO}_{2}$ であるから，

$1 F$ につき $1 / 2 \mathrm{~mol} \mathrm{C}_{2} \mathrm{H}_{6}+1 \mathrm{~mol} \mathrm{CO}=3 / 2 \mathrm{~mol}$ 気体 $1 F$ につき陽極に発生する気体総量を $\varphi \mathrm{mol}$ gas $/ F$ とし $\left\{\begin{array}{lr}\text { コルベ反空の電流效率 } & x \\ \text { コルベ反応以外の気体を発生しない副反応の効率 } y \\ \mathrm{O}_{2} \text { 発生のための効率 } & 1-(x+y)\end{array}\right.$ とすれば $\varphi=3 / 2 x+1 / 4\{1-(x+y)\}$

$$
a=1 / 4 \cdot\{1-(x+y)\} / \varphi, b=x / \varphi
$$

であるから， $a, b, \varphi$ を測定して $x, y$ を求めれば,

$$
x=b \varphi, y=1-b \varphi-4 a \varphi
$$

測定値より計算した值を Table 3 に示した.ただし， $\mathrm{CO}_{2} / 1 / 2 \mathrm{CH}_{4}+\mathrm{C}_{2} \mathrm{H}_{6}$ が央測では $1 / 0.5$ ではく，それぞ

Table 3 Anodic current efficiency of rhodium electrode

Electrolyte : Same as Table 1

Current efficiencies in the brackets are calculated from modified $\mathrm{CO}_{2} \%$, i.e. $1 / 0.5\left(1 / 2 \mathrm{CH}_{4}+\mathrm{C}_{2} \mathrm{H}_{6}\right)$ of Table 2

\begin{tabular}{c|c|c|c}
\hline $\begin{array}{l}\text { Current } \\
\text { density } \\
\left(\mathrm{A} / \mathrm{dm}^{2}\right)\end{array}$ & \multicolumn{3}{|c}{ Current efficiency (\%) } \\
\hline 10 & $77(75)$ & $17(17)$ & $6(8)$ \\
5 & $70(64)$ & $25(26)$ & $5(10)$ \\
\hline
\end{tabular}

れ，1/0.48，1/0.46 である. これはコルベ反応以外に $\mathrm{CO}_{2}$ を発生する反応を伴っているためと考えられるゆ え, $\mathrm{CO}_{2}$ の割合として $1 / 2 \mathrm{CH}_{4}+\mathrm{C}_{2} \mathrm{H}_{6}$ に 1/0.5 を乗じ た值を採用して計算した結果をかっこ内に示した.

\section{3 考察 (Discussion)}

Pt 極によるコルべ反応については，杉野，関根到によ る詳し々研究があってその結果では $5 M$ 電解液で,

$10.8 \mathrm{~A} / \mathrm{dm}^{2}$ 電流效率 $89 \%, \mathrm{CO}_{2} / \mathrm{CH}_{4}+\mathrm{C}_{2} \mathrm{H}_{6}=1 / 0.50$

$4.1 \mathrm{~A} / \mathrm{dm}^{2}$ 電流効率 $93 \%, \mathrm{CO}_{2} / \mathrm{CH}_{4}+\mathrm{C}_{2} \mathrm{H}_{6}=1 / 0.50$ である. 白金に比べロジウムでは同一電流密度で酸素発 生量が多いのは，その酸素過電圧の関係より当然である が，ロジウムの場合の特色はコルベ反応のほかに気体を 発生しない副反応が若干行なわれている点である。この 副反応は抬そらくエステルの生成, $\mathrm{CH}_{3} \mathrm{COO} \cdot+\mathrm{CH}_{3} \cdot \rightarrow$ $\mathrm{CH}_{3} \mathrm{COOCH}_{3}$ によるものと思われる. またロジウム陽 極の場合，発生ガス中に微量のメタンが認められる。こ れは

$$
\mathrm{CH}_{3} \cdot+\mathrm{CH}_{3} \mathrm{COOH} \rightarrow \mathrm{CH}_{4}+\cdot \mathrm{CH}_{2} \mathrm{COOH}
$$

の反応であろう。

\section{4 結 論 (Conclusion)}

ロジウム極を用いた場合，同䟴度の電解液にて白金極 を用いて陽極電解を行なった場合に比べて分極曲線の立 ち上がりが低電位であり，したがって陽極発生ガス中に は，酸素が多く，コルベ反応の勃率は Pt より低い。 た気体の発生を伴わない若干の副反応を伴うのむ特色で ある.

(Received April 28, 1969)

文

1) K. Sugino, S. Aoyagi, J. Electrochem. Soc. 103, 166 (1956); Bull. Chem. Soc. Japan 26, 185 (1953).

2) 電氮化学拹会媥 “軋気化学便臨” p. 819 (1964), 丸善.

3) 青柳 茂, 果京工業大学学報 (No. 1), (1959).

4）関根太郎，“最近における䉓函反忘論的考之方の工業への応用”, p. 147，(1964）有機電解，(要気化学拹会関東支部編）

5) K. Sugino, T. Sekine, N. Sato, Electrochem. Tech. 1, (No. 3-4), p. 112 (1963).

6）佐藤勋婎，関根太郎，祄野喜一郎，本誌 34，119 (1966). 